\title{
The Effect of Transformational Leadership Style on Organizational Commitment to Student Organizations
}

\author{
Fenti Hikmawati ${ }^{1}$, N. Kardinah ${ }^{2}$, Dicky Patria Darmawan ${ }^{3}$ \\ Department of Psychology, UIN Sunan Gunung Djati Bandung, Bandung, Indonesia ${ }^{1,2,3}$ \\ $\left\{\underline{\text { n.kardinah@uinsgd.ac.id }}{ }^{2}\right\}$
}

\begin{abstract}
This study aims to determine how much influence the transformational leadership style has on an organizational commitment to student organizations, which in this study is a psychology student organization at Sunan Gunung Djati UIN Bandung, namely: Psychorescue. The method used in this study is quantitative with simple linear regression analysis with 40 subjects of Psychorescue members. The scale of transformational leadership style used is based on the theory of Bass and Avolio, while the organizational commitment used is based on the theory of J.P Meyer \& J.J. Allen, both of which were made by researchers. The results showed that transformational leadership style had a significant effect of $67 \%$ on an organizational commitment to members of Psychorescue. The hypothesis testing obtained results of $t$-count of 8.769 while $t-$ table with a significance level of $5 \%$ is $\mathrm{df}=\mathrm{N}-2$, then $\mathrm{df}=40-2=38$ which is equal to 2,024 . So that $t$ count is $8.769>t$-table which is 2.024 . This means that there is a significant effect of transformational leadership style on organizational commitment in Psychorescue members or it can be said that $\mathrm{H} 1$ is accepted and $\mathrm{H} 0$ is rejected.
\end{abstract}

Keywords: Psychorescue, Leadership, Commitment

\section{Introduction}

Non-formal activities in higher education based on principles are held by students, from students, and for students is the meaning of student organizations [1]. The presence of students who gather and collaborate in organizations is not without reason, they have a goal to be achieved. From the facilities and infrastructure, they hold to channel student hobbies, develop student potential, and even conduct organizational learning. According to [2] container to develop reasoning abilities, hobbies, hobbies, interests, and talents of students which can be through student organizations. Then reinforced by the Minister of Education and Culture of the Republic of Indonesia. No. 155 / U / 1998 concerning general guidelines for student organizations in higher education, that to broaden horizons, increase scholarship and build personality integrity in achieving educational goals, can be through student development or extracurricular means which are also definitions of college student organizations. From the results of observations of researchers in 2016, the fact that the field continued that the activities of the Psychorescue organization were inseparable from the role of its leaders. The existence of a leader in an activity is able to make the number of members' attendance more, 
the leader's motivation and clear direction make members take more attitudes to be present in the activities of Psychorescue.

\section{Method}

In this study using a quantitative approach, to see the effect of independent variables on the dependent variable, simple regression analysis was used. This study aims to determine the effect of transformational leadership organizational on commitment organizations on Psychorescue members. The scale of the instrument used in this study is the Likert scale of transformational leadership style and organizational commitment.

\section{Result and discussion}

\subsection{Result}

\subsubsection{Descriptive Analyses}

The results of the descriptive analysis of the data variables are obtained by the average value of the transformational leadership style variable, 118.68 with a standard deviation of 17,666. While the organizational commitment variable the average value is 105.95 and the standard deviation is 15,635 . Also obtained as many as $13.5 \%$ respondents with a high-quality transformational leadership style and 27 respondents with presentations of $67.5 \%$ had a lowquality transformational leadership style.It is known that respondents who have high organizational commitment if they have a score of more than equal and are said to be low if they have a less than 105 score. Have low organizational commitment.

\subsubsection{Inferential Analyses}

In the calculation of determination, coefficient obtained r-value of 0.699 , then next to find out how much influence the independent variable on the dependent variable using the coefficient of determination $r^{2}$ expressed in percentage, with a result of $67 \%$. From the results of the above calculations, it can be concluded that there is an influence of the Transformational Leadership Style on Organizational Commitment to Psychorescue members is $67 \%$ and the remaining $33 \%$ is influenced by other factors not examined. In the classification of Guilford determination, this score includes very high influence.

The results of the calculation of a simple linear regression equation obtained constant coefficients is equal to 20.022 and free coefficient $(\mathrm{X})$ of 0.724 so that the regression equation is obtained as follows:

$\hat{\mathrm{Y}}=20,022+0.724 \mathrm{X}$

Information:

$\mathrm{Y}=$ Organizational Commitment

$\mathrm{X}=$ Transfational Leadership Style

Based on the regression equation obtained a constant value of 20.022 indicates that if organizational commitment 0 then the transformational leadership style is 20.022 . Furthermore, the value of 0.724 which is positive on regression coefficient variable organizational commitment illustrates that there is a unidirectional relationship between transformational leadership style and organizational commitment, where each increase in one 
scale of transformational leadership style will cause an increase in organizational commitment of 0.724 .

The results of simple linear regression coefficients have a significance value of 0.000 $<0.05$ which means that there is a significant effect of transformational leadership style on an organizational commitment to members of Psychorescue. Obtained results of a t-test of 8.769 to find the value of $t$-table then do the following calculation: $t$-table for the significance level of $5 \%$ is $\mathrm{df}=\mathrm{N}-2$, then $40-2=38$ which is equal to 2,024 . So that t-test is $8.769>\mathrm{t}$-table is 2.024. That is, there is a significant effect of Transformational Leadership Style on Organizational Commitment to Psychorescue members, or it can be said that $\mathrm{H}_{1}$ is accepted and $\mathrm{H}_{0}$ is rejected.

\subsection{Discussion}

This study aims to determine whether there is an influence of transformational leadership style on an organizational commitment to members of the psycho-rescue. This means that a transformational leadership style influences organizational commitment to members of the psycho-rescue. The results of the regression analysis also obtained the results of the coefficient of determination ( $\mathrm{R}$ Square), which amounted to $67 \%$, meaning the value of transformational leadership style on organizational commitment in psycho rescue members in the classification of Guilford determination was very high, while $33 \%$ was caused by other factors not explained in this research. In addition, there is also a regression equation $\mathrm{Y}=$ $20,022+0.724 \mathrm{X}$. In this case that there is a unidirectional relationship between transformational leadership style and organizational commitment, where every one scale increases in transformational leadership style will cause an increasing in organizational commitment of 0.724 .

Such as the research by Pratini and Utama, transformational leadership and organization cultures have positive and significant effect on motivation and performance [3]. Then leadership style and compensation has positive effect on employee job satisfaction [4]. The last, leadership style and job motivation have greater effect on organization commitment [5].

The researcher has an illustration that when transformational leaders in the lead process have aspects developed by Bass and Avolio, such as individual considerations, give intellectual encouragement, provide motivation, and have good ideal influences as to what they say. Making it possible to make conditions conducive to the environment, followers can become more empowered and make their followers more comfortable. This can be seen from the fact the results of interviews with five members of Psychorescue on the page of the Psychology Faculty of UIN Bandung on July 28, 2017, when asked about "feelings and situations that occur after being led by a new leader". Almost the same answer they feel if the behavior of their comrades becomes less committed in the organization and they tend to need leaders who are in line with transformational characters because many potential members are not effectively deceived.

The organizational commitment is the relationship between individuals and organizations where they work, where individuals believe in the values and goals of the organization, there is a willingness to give their business seriously for the sake of the organization and have a strong desire to remain part of the work organization. Researchers have a picture that a follower who is committed to the organization is certainly caused by many factors. But of the many factors, a follower can commit to his organization because of his organizational leadership style. This can be seen from the results of the descriptive analysis which shows that $40 \%$ of psycho-rescue members have high organizational commitment. Then the data is 
reinforced by Heller [6], say if followers commitment can be obtained due to the quality and leadership style that are the main factors. He added when leadership style is the main factor, then the second, third, and so on factors are other consequences of the commitment of followers.

As an organization in running an organizational system, Psychorescue definitely needs a leader who can manage, influence, and direct its members to achieve common goals. According to Greenberg and Baron in [6], the existence of leaders in the organization will greatly influence its members. Robbins [6] a leader is a source of formal or occupational influence, the source is in the form of leadership, and leadership is the ability to influence a group towards achieving goals.

According to Griffin in [7], explain the notion of leadership divided into two concepts one of which is the process. As a process, leadership is focused on where leaders use their influence to clarify the organization. According to Hersey [8], behavior that includes movement, words, and actions of a leader who then feels that the influence of the behavior of members is meaning of leadership style. Strengthened by Tjiptono in [8] the way leaders interact with their subordinates is part of the definition of leadership style.

The importance of leadership in an organization is expressed by experts, among others, according to Waluyo in [9] the bad or bad elements of the organization can be a reflection of the leader, because leadership is the main element in an organization. Strengthened by Gibson, Ivancevich, Donnelly, and Konopaske [6] the importance of being an agent of change, focusing on one goal, interpersonal relations, and the use of influence are important functions of leadership. If a leader leads an organization it means that there is a process influencing, and influencing this has a variety of styles, called leadership style.

\section{Conclusion}

This study aims to determine the effect of transformational leadership style on an organizational commitment to Psychorescue student organizations. The results of the above calculations it can be concluded that there is an influence of the Transformational Leadership Style on Organizational Commitment to Psychorescue members is 67\% and the remaining 33\% is influenced by other factors not examined. The correlation between Transformational Leadership Style on Organizational Commitment to Psychorescue members has correlate positively in which when transformational leadership increases one scale then organizational commitment increases 0.724 on Psychorescue members.

\section{References}

[1] S. Sukirman, Tuntunan Belajar di Perguruan Tinggi. Jakarta: Pelangi Cendikia, 2004.

[2] P. Sudarman, Belajar Efektif di Perguruan Tinggi. Bandung: Simbiosa Rekatama Media, 2004.

[3] P. Pratini and I. W. M. Utama, "Pengaruh Kepemimpinan Transformasional Dan Budaya Organisasi Terhadap Motivasi Dan Kinerja Karyawan,” E-Jurnal Manaj. Unud, vol. 5, no. 7, pp. 4337-4366, 2016.

[4] M. D. Ilmawan, D. S. Wulandari, and F. Fitriani, "Peran Gaya Kepemimpinan dan Kompensasi dalam Mempengaruhi Kinerja yang Dimediasi oleh Kepuasan Kerja," $J$. Ekon. Mod., vol. 13, no. 1, p. 37, Jun. 2017.

[5] B. P. Fabio, M. Hubeis, and H. Puspitawati, "Pengaruh Gaya Kepemimpinan, 
Motivasi Kerja terhadap Komitmen Organisasi yang Berimplikasi pada Kinerja Karyawan," J. Apl. Bisnis dan Manaj., vol. 2, no. 1, pp. 91-104, 2016.

[6] Wibowo, Perilaku Dalam Organisasi, Edisi Kedua. Jakarta: Rajawali Pers, 2013.

[7] E. I. Andriyani, "Pengaruh Gaya Kepemimpinan Terhadap Kinerja Karyawan," Sanata Dharma University, 2016.

[8] R. Tia, "Pengaruh Gaya Kepemimpinan Dan Budaya Organisasi Terhadap Kinerja Karyawan Melalui Motivasi Kerja (Studi Pda Auti 2000 Raden Intan Lampung)," Universitas Lampung, 2015.

[9] S. Riyan, "Pengaruh Gaya Kepemimpinan Demokratis Presiden Bem Unila Terhadap Pembentukan Dinamika," Universitas Lampung, 2014. 